\title{
Identity of Gymnophthalmus (Squamata: Gymnophthalmidae) from northeastern Amazonia with evidence for $G$. underwoodi as invasive in Belém
}

\author{
Adriano O. MACIEL ${ }^{1 *}$ (๑), Ivanei S. ARAÚJO², Geraldo R. LIMA-FILHO 3 , Felipe M. R. CASTRO ${ }^{4}$, \\ Lywouty R. S. NASCIMENTO5, Manuela V. dos SANTOS 5 , Ana L. C. PRUDENTE ${ }^{3,4,5,6}$, Marcelo J. STURARO $^{7}$ \\ ${ }^{1}$ Museu Paraense Emílio Goeldi, Coordenação de Zoologia, Programa de Capacitação Institucional, Belém, Pará, Brazil \\ ${ }^{2}$ Museu Paraense Emílio Goeldi, Laboratório de Entomologia, Belém, Pará, Brazil \\ ${ }^{3}$ Museu Paraense Emílio Goeldi, Laboratório de Biologia Molecular, Belém, Pará, Brazil \\ ${ }^{4}$ Universidade Federal do Pará, Programa de Pós-Graduação em Zoologia, Belém, Pará, Brazil \\ ${ }^{5}$ Museu Paraense Emílio Goeldi, Programa de Pós-Graduação em Biodiversidade e Evolução, Belém, Pará, Brazil \\ ${ }^{6}$ Museu Paraense Emílio Goeldi, Coordenação de Zoologia, Laboratório de Herpetologia, Belém, Pará, Brazil \\ 7 Universidade Federal de São Paulo, Departamento de Ecologia e Biologia Evolutiva, Diadema, SP, Brazil \\ *Corresponding author: aombiologo@yahoo.com.br; (D) https://orcid.org/0000-0001-5901-1896
}

\section{ABSTRACT}

We report the occurrence of the lizard Gymnophthalmus underwoodi in the municipality of Belém, state of Pará, Brazil. This is the first record of that species south of the Amazonas River, probably because of an accidental introduction by ships that dock in Belém, the same pathway suggested for the recent introduction of another species of exotic lizard recently recorded in the city. We also determined the identity of some specimens of Gymnophthalmus from the states of Amapá and Pará through external morphology and molecular data, confirming that, until now, G. vanzoi is the only Gymnophthalmus occurring in the savanna enclaves of those states. Finally, we provide a new distribution map for the species of Gymnophthalmus, including the new occurrence record for $G$. underwoodi for the state of Pará, where it can be considered as an invasive species.

KEYWORDS: exotic fauna, lizards, South America, DNA, morphology

\section{Identidade dos Gymnophthalmus (Squamata: Gymnophthalmidae) do nordeste da Amazônia, com evidência para G. underwoodi como invasora em Belém}

\section{RESUMO}

Nós relatamos a ocorrência do lagarto Gymnophthalmus underwoodi no município de Belém, estado do Pará, Brasil. Este é o primeiro registro ao sul do Rio Amazonas, provavelmente como resultado de uma introduçáo acidental por navios que atracam em Belém, o mesmo caminho sugerido para a introdução de outra espécie exótica de lagarto recentemente encontrada na cidade. Nós também determinamos a identidade de alguns espécimes de Gymnophthalmus dos estados do Amapá e Pará, através de dados morfológicos externos e moleculares, confirmando que, até o momento, G. vanzoi é o único Gymnophthalmus ocorrendo nos enclaves de savana desses estados. Por fim, nós fornecemos um novo mapa de distribuição para as espécies de Gymnophthalmus, incluindo o novo registro de ocorrência de G. underwoodi para o estado do Pará, onde ela pode ser considerada como uma espécie invasiva.

PALAVRAS-CHAVE: fauna exótica, lagartos, América do Sul, ADN, morfologia

\section{INTRODUCTION}

Gymnophthalmus Merren, 1820 includes eight species of diminutive lizards that inhabit areas of open vegetation and the litter of forests in Central America, the Antilles, and northern South America, mainly north of the Amazonas River (AvilaPires 1995; Ribeiro-Júnior and Amaral 2017; Recoder et al.
2018). In Brazil, there are three species known sensu Recoder et al. (2018), namely: Gymnophthalmus leucomystax Vanzolini and Carvalho, 1991, found in the northeastern part of the state of Roraima; Gymnophthalmus underwoodi Grant, 1958, present in the states of Amazonas (north of the Amazonas River) and Roraima; and Gymnophthalmus vanzoi Carvalho, 1999, found in the states of Amapá, Pará and Roraima.

CITE AS: Maciel, A.O.; Araújo, I.S.; Lima-Filho, G.R.; Castro, F.M.R.; Nascimento, L.R.S.; Santos, M.V. d.; Prudente, A.L. C.; Sturaro, M.J. 2021. Identity of Gymnophthalmus (Squamata: Gymnophthalmidae) from northeastern Amazonia with evidence for G. underwoodi as invasive in Belém. Acta Amazonica 51: 291-297. 
Two species have been taxonomically confusing herpetologists collecting in northeastern Amazonia (Recoder $e t$ al. 2018). The first, $G$. underwoodi, is a parthenogenetic species (Hardy et al. 1989; Cole et al. 1990) possibly originating from the hybridization between a maternal lineage closely related to G. cryptus and a paternal lineage of G. speciosus (Kizirian and Cole 1999). The second species, G. vanzoi, is a sexual species with disjunct populations throughout Amazonia that show some color variation, but with extremely low genetic divergence (Recoder et al. 2018).

Despite the extensive taxonomic review on Gymnophthalmus by Recoder et al. (2018), minor questions remain regarding the status of some specimens from geographically isolated areas of savanna in the states of Amapá and Pará (Brazil) that were mentioned with inaccurate identification by Avila-Pires $e t$ al. (2010) and Ribeiro-Júnior and Amaral (2017). There are also some surprising records of specimens of Gymnophthalmus recently collected in different points of the municipality of Belém, state of Pará, where no species of the genus was known to occur. Using molecular and morphological data, we evaluated the taxonomic status of specimens recently collected in northeastern Amazonia, including specimens from localities not reviewed by Recoder $e t$ al. (2018) and in Belém south of the Amazonas River.

\section{MATERIAL AND METHODS}

We analyzed eight specimens of Gymnophthalmus from the states of Amapá and Pará, Brazil, housed in the herpetological collection (Coleção Herpetológica Osvaldo Rodrigues da Cunha) of Museu Paraense Emílio Goeldi (MPEG), Belém, Pará, Brazil. Three specimens are from enclaves of savanna located within the distribution of $G$. vanzoi reported by Recoder et al. (2018), but they were not analyzed morphologically nor molecularly by the latter authors. One of these three specimens (MPEG 27592), from Óbidos, Pará, was referred as Gymnophthalmus cf. underwoodi by Avila-Pires et al. (2010) and as an undescribed Gymnophthalmus by Ribeiro-Júnior and Amaral (2017). The other two (MPEG 29841 and 29844) from Mazagão, Amapá, were catalogued as Gymnophthalmus sp.

Five recently collected specimens are from four localities in the municipality of Belém, Pará, Brazil (Table 1; Figure 1), in two districts bordering the Guajará River, which is formed by the confluence of the Acará and Guamá Rivers. Four specimens were found in the district of Icoaraci. The first (MPEG 33550) was collected on October 2, 2012, inside a residence, 100

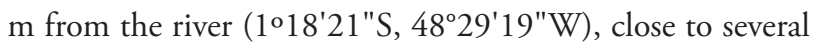
small ports which receive passanger and product transport vessels from Marajó Island and other nearby regions. On August 27, 2019, two more specimens (MPEG 33157 and MPEG 33158) (Figure 2) were collected at a second locality $\left(1^{\circ} 18^{\prime} 44^{\prime \prime} \mathrm{S} ; 48^{\circ} 27^{\prime} 53^{\prime \prime} \mathrm{W}\right), 2.8 \mathrm{~km}$ further inland. The fourth specimen (MPEG 33546) was collected on August 16, 2020, at a third locality $2.9 \mathrm{~km}$ from the first and $2.7 \mathrm{~km}$ from the second locality (1'19'49.2"S; 48 $\left.28^{\prime} 37.4^{\prime \prime W}\right)$. Finally, a single specimen (MPEG 33549) was collected in the district of Mosqueiro Island ( $\left.1^{\circ} 4^{\prime} 3.1^{\prime \prime S}, 48^{\circ} 21^{\prime} 15.8^{\prime \prime} \mathrm{W}\right)$ on November $5,2020,29 \mathrm{~km}$ from the closest locality in Icoaraci and 700 $\mathrm{m}$ from the river margin. The latter four specimens were found among underbrush vegetation in backyards of houses.

We examined nine morphological characters to assess the variation in the studied specimens and confirm their identity (Table 1) by comparison with the parameter ranges presented

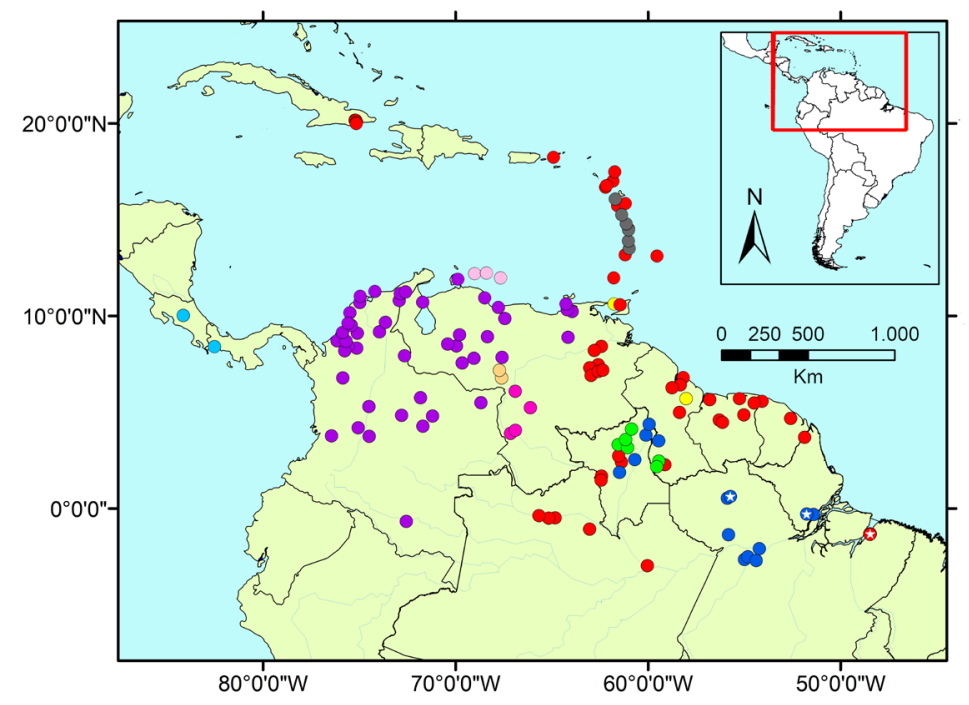

Figure 1. Geographic distribution of Gymnophthalmus: G. speciosus (light blue); G. cf. speciosus (purple); G. marconaterai (orange); G. lineatus (light pink); G. cryptus (dark pink); G. underwoodi (red); G. pleei (dark gray); G. leucomystax (green); G. vanzoi (blue); G. aff. vanzoi (yellow). Stars within the occurrence symbol indicate specimens sequenced in this study. Localities are mostly based on the map of Recoder et al. (2018) plus records of G. underwoodi for Cuba (Alfonso et al. 2012; Alfonso and Hernandez, 2017). This figure is in color in the digital version. 
Table 1. Qualitative, morphometric ( $\mathrm{mm}$ ) and meristic data for specimens of Gymnophthalmus underwoodi and G. vanzoi from the states of Amapá and Pará analyzed in this study. See Material and Methods for acronym definition. na = data not available due to tail broken by autotomy.

\begin{tabular}{lccccccccccccc}
\hline Species & Locality & Voucher & Sex & SVL & DOR & VEN & GUL & SAM & LFT & LFF & SCA & SPL & Pores \\
\hline Gymnophthalmus vanzoi & Óbidos, Pará & MPEG 27592 & female & 40 & 32 & 27 & 9 & 13 & 16 & 12 & 41 & 14 & absent \\
Gymnophthalmus vanzoi & Mazagão, Amapá & MPEG 29841 & male & 35 & 32 & 24 & 9 & 13 & 14 & 11 & na & 14 & present \\
Gymnophthalmus vanzoi & Mazagão, Amapá & MPEG 29844 & male & 35 & 31 & 23 & 9 & 13 & 14 & 11 & na & 14 & present \\
Gymnophthalmus underwoodi & Icoaraci, Belém, Pará & MPEG 33157 & female & 37.5 & 31 & 24 & 9 & 13 & 18 & 13 & na & 14 & absent \\
Gymnophthalmus underwoodi & Icoaraci, Belém, Pará & MPEG 33158 & female & 44 & 32 & 24 & 9 & 13 & 17 & 14 & na & 14 & absent \\
Gymnophthalmus underwoodi & Icoaraci, Belém, Pará & MPEG 33546 & female & 20 & 32 & 24 & 10 & 13 & 15 & 13 & 27 & 14 & absent \\
Gymnophthalmus underwoodi & Mosqueiro, Belém, Pará & MPEG 33549 & female & 19 & 32 & 22 & 9 & 13 & 15 & 14 & 24 & 13 & absent \\
Gymnophthalmus underwoodi & Icoaraci, Belém, Pará & MPEG 33550 & female & 18.3 & 31 & 22 & 9 & 13 & 15 & 14 & na & 14 & absent \\
\hline
\end{tabular}

in the Table 4 of Recoder et al. (2018). The acronyms of one morphometric and eight meristic data follow Recoder $e t$ al. (2018): snout-vent length (SVL), number of dorsal transversal rows (DOR); number of ventral transversal rows (VEN); gular transversal rows (GUL); scales around midbody (SAM); lamellae under the fourth toe (LFT); lamellae under the fourth finger (LFF); number of smooth subcaudal scales (SCA); and total number of supralabials on both sides (SPL). The sex of the specimens was identified by the presence (males) or absence (females) of femoral pores.

We extracted DNA from muscle samples preserved in $100 \%$ ethanol of four specimens (Table 2) using the Wizard ${ }^{\circ}$ Genomics DNA Purification Kit (Promega, Madison, WI, USA), following the manufacturer's recommended protocol for animal tissue (mouse tail) and quantified the extract in Qubit. We amplified the products with PCR Master Mix, 2X (Promega) with $10 \mu \mathrm{L}$ reactions for two mitochondrial markers following a standard $4 \mathrm{~min}$ initial denaturation at $94^{\circ} \mathrm{C}$ and a final extension of 6 min at $72^{\circ} \mathrm{C}$, with primers by Benavides et al. (2007) for $12 S$ [95 (30") / 50 $\left(60^{\circ}\right) / 72^{\circ}\left(60^{\prime \prime}\right)$ [35x]] and by Geurgas et al. (2008) and Whiting et al. (2003) for $16 \mathrm{~S}$ $\left[95^{\circ}\left(30^{\prime \prime}\right) / 45^{\circ}\left(30^{\prime \prime}\right) / 72^{\circ}\left(60^{\prime \prime}\right)[35 \mathrm{x}]\right]$. We purified the PCR products using ExoSAP-IT, following the 5-min recommended protocol. We sequenced purified reactions using the specific primers and BigDye 3.1 cycle sequencing chemistry (Applied Biosystems) following the manufacturer's recommended protocol and cycling conditions on an Applied Biosystems 3100 automated capillary sequencer, producing two strands (forward and reverse). All procedures were conducted in the Molecular Biology Laboratory of MPEG. All sequences were deposited in Genbank. We also included in our analysis the sequences of other 29 specimens of seven species of Gymnophthalmus and one sequence of a Micrablepharus maximiliani used as outgroup (Table 2). All sequences were obtained from GenBank.

We edited the sequences using BioEdit (Hall 1999) and the alignments were made using MAFFT version 7 (Kuraku et al. 2013; Katoh et al. 2019). We choose the strategy Q-INS-I for both ribosomal $12 S$ and $16 S$ because this method considers the secondary structure of RNA (Katoh et al. 2005; Katoh and Toh 2008). Alignments were concatenated in Sequence Matrix version 1.7.8 (Vaidya et al. 2011), and the best scheme of partitioning

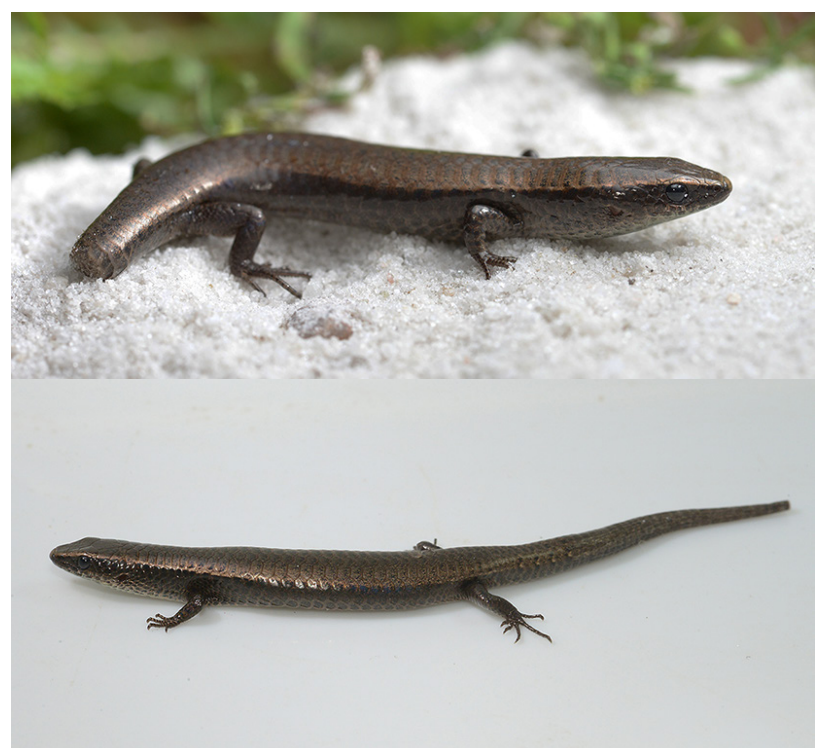

Figure 2. Specimens of Gymnophthalmus underwoodi from Belém, Pará, Brazil [MPEG 33157 (top) and MPEG 33158 (bottom)]. This figure is in color in the digital version.

and substitution models was chosen using PartitionFinder version 2 (Lanfear et al. 2017) in version 3.3 of the CIPRES web portal (Miller et al. 2010). For the phylogenetic positioning of our samples, we ran a maximum likelihood analysis in RAxML version 8 (Stamatakis 2014) using version 3.3 of the CIPRES web portal (Miller et al. 2010). The bootstrap analysis was implemented with 1000 pseudoreplicates. Finally, the bipartition support was drawn on the best likelihood tree.

\section{RESULTS}

The phylogenetic analysis indicated that all specimens we analyzed from north of the Amazonas River (MPEG 27592, 29841 and 29844) are Gymnophthalmus vanzoi (Figure 3), while the specimen from Belém (MPEG 33517) was recovered as Gymnophthalmus underwoodi (Figure 3). In the morphological analysis, we found that in eight of the nine analyzed characters all northern specimens were very similar to the specimens from Belém (MPEG 33157, 33158, 33546, 33549, and 33550) (Table 1). Gymnophthalmus underwoodi 
Table 2. List of specimens sampled for molecular analysis in this study. Codes in the columns $12 \mathrm{~S}$ and $16 \mathrm{~S}$ are GenBank accession numbers. Taxa in bold were sequenced exclusively for this study. na = data not available.

\begin{tabular}{|c|c|c|c|c|c|}
\hline Species & Voucher number & Locality & Country & $12 S$ & $16 S$ \\
\hline Gymnophthalmus vanzoi & MPEG 27592 & Óbidos, Pará & Brazil & MZ544008 & na \\
\hline Gymnophthalmus vanzoi & MPEG 29841 & Mazagão, Amapá & Brazil & MZ544009 & MZ544020 \\
\hline Gymnophthalmus vanzoi & MPEG 29844 & Mazagão, Amapá & Brazil & MZ544010 & MZ544021 \\
\hline Gymnophthalmus vanzoi & MTR 33447 & Santarém, Pará & Brazil & MH732644 & MH732695 \\
\hline Gymnophthalmus vanzoi & APSJ 235 & Santarém, Pará & Brazil & MH732646 & MH732698 \\
\hline Gymnophthalmus vanzoi & APS 73 & Santarém, Pará & Brazil & MH732647 & MH732697 \\
\hline Gymnophthalmus vanzoi & UFOPA 0373 & Santarém, Pará & Brazil & MH732645 & MH732696 \\
\hline Gymnophthalmus vanzoi & MTR 946484 & Boa Vista, Roraima & Brazil & MH732648 & MH732699 \\
\hline Gymnophthalmus vanzoi & MTR 946487 & Boa Vista, Roraima & Brazil & MH732649 & MH732700 \\
\hline Gymnophthalmus vanzoi & MTR 946490 & Boa Vista, Roraima & Brazil & MH732650 & MH732701 \\
\hline Gymnophthalmus vanzoi & LSUMZ 12396 & Boa Vista, Roraima & Brazil & MH732651 & MH732702 \\
\hline Gymnophthalmus vanzoi & MTR 946529 & Uiramutã, Roraima & Brazil & MH732653 & MH732708 \\
\hline Gymnophthalmus vanzoi & MTR 946527 & Uiramutã, Roraima & Brazil & MH732652 & MH732707 \\
\hline Gymnophthalmus vanzoi & MTR 946534 & Uiramutã, Roraima & Brazil & MH732654 & MH732706 \\
\hline Gymnophthalmus vanzoi & MTR 946500 & Normandia, Roraima & Brazil & MH732656 & MH732705 \\
\hline Gymnophthalmus vanzoi & MTR 946501 & Normandia, Roraima & Brazil & MH732657 & MH732703 \\
\hline Gymnophthalmus vanzoi & MTR 946498 & Normandia, Roraima & Brazil & MH732655 & MH732704 \\
\hline Gymnophthalmus vanzoi & AMNH-R-138029 & Northern Rupununi Savanna & Guyana & MH732658 & na \\
\hline Gymnophthalmus vanzoi & AMNH-R-138040 & Northern Rupununi Savanna & Guyana & MH732659 & na \\
\hline Gymnophthalmus vanzoi & AMNH-R-138055 & Northern Rupununi Savanna & Guyana & AF101368 & AF101368 \\
\hline Gymnophthalmus aff. vanzoi & AMNH-R-128438 & St. George & Trinidad \& Tobago & MH732643 & MH732709 \\
\hline Gymnophthalmus aff. vanzoi & FT1389/JC4823 & St. George & Trinidad \& Tobago & AF101365 & AF101365 \\
\hline Gymnophthalmus aff. vanzoi & AMNH-R-140975 & Berbice River & Guyana & AF101366 & AF101366 \\
\hline Gymnophthalmus underwoodi & MPEG 33517 & Belém, Pará & Brazil & na & MZ544022 \\
\hline Gymnophthalmus underwoodi & MTR 946601 & Ilha de Maracá, Roraima & Brazil & MH732661 & MH732711 \\
\hline Gymnophthalmus underwoodi & MTR 946590 & Ilha de Maracá, Roraima & Brazil & MH732662 & KT254406 \\
\hline Gymnophthalmus underwoodi & APL 21703 & Manaus, Amazonas & Brazil & MH732663 & MH732712 \\
\hline Gymnophthalmus underwoodi & JC/FT7054 & Sam Lord's Castle, St. Phillip & Barbados & AF101369 & AF101369 \\
\hline Gymnophthalmus underwoodi & NYSM 6432 & Bottomless Ghaut & Montserrat & na & KX866265 \\
\hline Gymnophthalmus speciosus & MTR 33465 & San José & Costa Rica & MH732660 & MH732710 \\
\hline Gymnophthalmus cryptus & AMNH-R-138374 & San Juan de Manapiare & Venezuela & AF101362 & AF101362 \\
\hline Gymnophthalmus leucomystax & AMNH-R-139857 & Southern Rupununi Savanna & Guyana & MH732666 & MH732714 \\
\hline Gymnophthalmus pleei & AMNH-R-128428 & Martinique & West indies & AF101364 & AF101364 \\
\hline Micrablepharus maximiliani & LG 1017 & Barra do Garças, Mato Grosso & Brazil & AF420657 & AF420730 \\
\hline
\end{tabular}

and G. vanzoi are known to be very similar in the traditionally used external morphological characters (Recoder et al. 2018), but we distinguished the northern specimens (G. vanzoi) from the Belém specimens ( $G$. underwoodi) in the number of smooth subcaudal scales (SCA) (Table 1).

The number of SCA in G. vanzoi varies from 32 to 55 (Recoder et al. 2018), and we found 41 SCA in MPEG 27592, which is the single lizard with a whole tail among the three specimens from north of the Amazonas River. The SCA in G. underwoodi ranges from 23 to 26 (Recoder $e$ a al. 2018), and we found 24 and 27 SCA in MPEG 33549, and 33546, respectively. Therefore, although we cannot confirm indisputably the identity of all specimens based on morphology, at least we could confirm that all specimens from north of the Amazonas River are G. vanzoi in the molecular phylogeny. We confirmed the identity as G. underwoodi for three of the five specimens from Belém (one based on the molecular phylogeny and two by the number of SCA), and it is very likely that the other two individuals belong to the same species. Thus we assume that only $G$. underwoodi is present in Belém to date.

\section{DISCUSSION}

Our results confirm the designation as Gymnophthalmus vanzoi of Recoder et al. (2018) for Gymnophthalmus from north of the Amazonas River in the states of Amapá and Pará and show that the color differences reported as a differential characteristic of specimen MPEG 27592 from G. vanzoi by Avila-Pires et al. (2010) are not supported by molecular and meristic data, although future studies integrating more data 


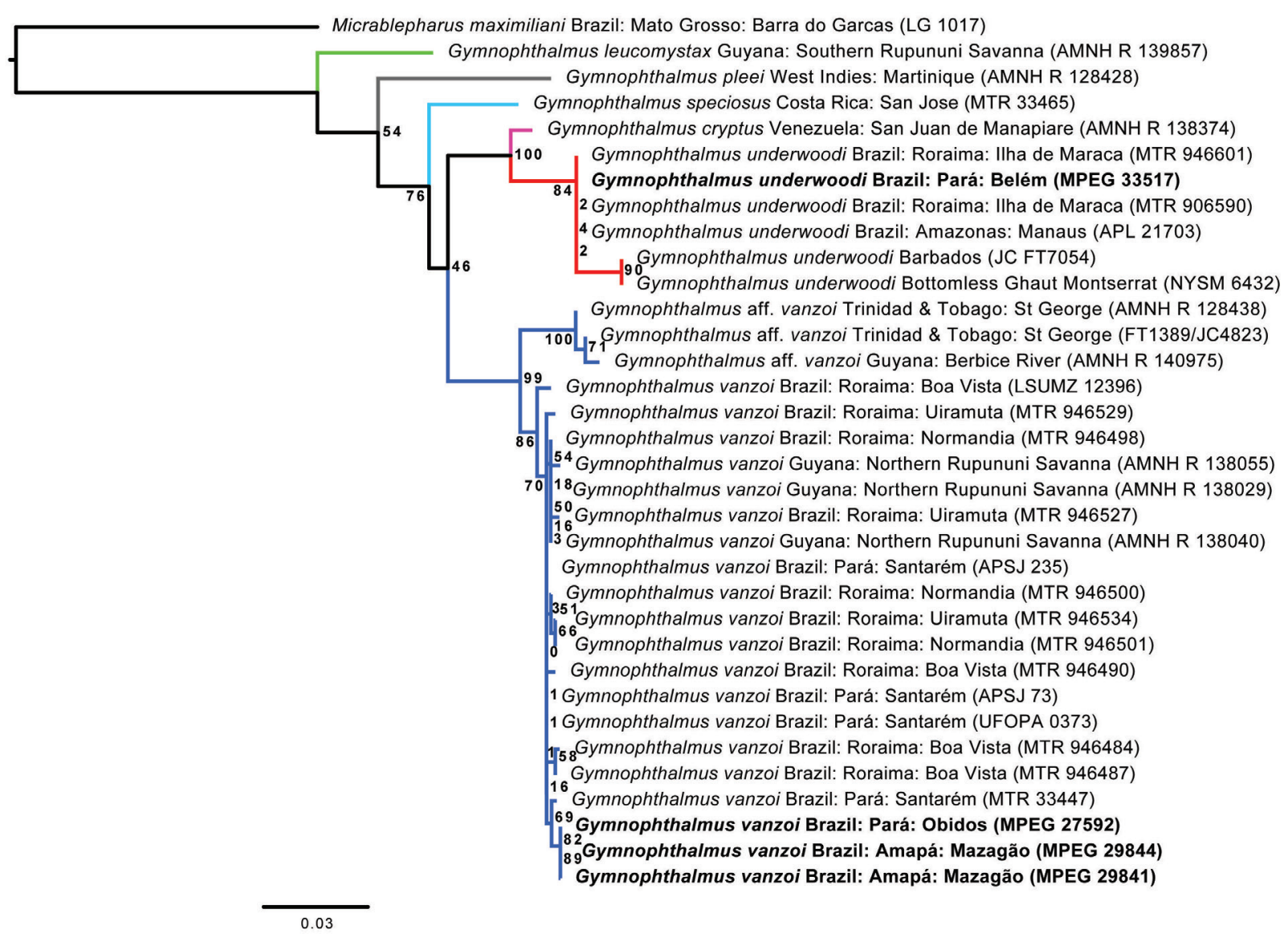

Figure 3. Maximum likelihood phylogram of Gymnophthalmus (1000 searches, loglikelihood = -2720.336686). Taxa labeled in bold were sequenced exclusively for this study. Colors correspond to the species codes in Figure 1. This figure is in color in the digital version.

can be important to reevaluate the taxonomic importance of color variation among the populations of this species.

The Belém region is one of the best studied areas in the Brazilian Amazon for herpetofauna, yet there existed no previous record of $G$. underwoodi in this area (Rand and Humphrey 1968; Avila-Pires 1995; Galati et al. 2007; AvilaPires et al. 2018; Prudente et al. 2018), which is approximately $600 \mathrm{~km}$ away from the closest known occurrence of the species, in northeastern French Guiana. This strongly suggests that $G$. underwoodi does not occur naturally in the Belém municipality, but originates from an anthropic introduction. Further herpetological surveys in Belém and the wider Pará state, as well as refined molecular analyses involving larger samples from the entire distribution range of the species should elucidate the origin of the specimens found in the city.

Gymnophthalmus underwoodi was described from Barbados in the Lesser Antilles (Grant 1958) and was posteriorly found in the western and northern part of the Guiana region (Hoogmoed 1973; Avila-Pires 1995; Recoder et al. 2018). Kizirian and Cole (1999) suggested that G. underwoodi dispersed from South America to some Caribbean islands, since this species originated from the hybridization of two continental lineages and may have been transported through drift material from rivers that flow into the Caribbean Sea. Today, $G$. underwoodi is recognized to be invasive in several islands in the Lesser and Greater Antilles, where it can occur in sympatry with other native and non-native species of lizards (Orchard 2010; Turk et al. 2010; Breuil and Serre-Collet 2012; Questel and Boggio 2012; Alfonso and Hernandez 2017; Snyder et al. 2017).

The collection site of the $G$. underwoodi specimens in Belém (in an urban environment near a fluvial port) suggests the possibility of an introduction through a vessel docked at the port. Hoogmoed and Avila-Pires (2015) recently reported the presence in Belém of the lizard Lepidodactylus lugubris (Duméril and Bibron 1836), an Asiatic species of Gekkonidae introduced in several countries in the Caribbean region, and Central and South America. Discussing the origin of the L. lugubris specimens from Belém, the latter authors cited a shipping company that started to transport containers from Guadeloupe and Suriname to Belém in 2012 as a possible way for the introduction of the 
species in the city. In this context, it is noteworthy that the first G. underwoodi was recorded in Belém in late 2012, but we cannot precisely define the entry pathway of the species in the city. Furthermore, G. underwoodi is also present in Guadeloupe (Breuil and Serre-Collet 2012) and Suriname (Kizirian and Cole 1999), reinforcing the alert for a possible route for the introduction of species in the Brazilian Amazon.

The reiterated record of individuals of $G$. underwoodi in different localities in Belém over nine years suggests that the species is establishing a population in the region. Future studies should confirm whether $G$. underwoodi can establish and expand its occurrence in the region of Belém. The most recent record (2020) was on Mosqueiro Island, which is connected to the mainland by a bridge and features no large harbor. The presence of $G$. underwoodi on Mosqueiro may represent a secondary introduction by small boats that transport products from the mainland or even by terrestrial vehicles from Icoaraci. D'Angiolella et al. (2021) recently reported new records of $L$. lugubris further inland in the state of Pará, which shows a fast territorial expansion of the species. Both $G$. underwoodi, and L. lugubris are parthenogenetic, which can be a great advantage for colonizing new areas, as a single individual is necessary to start reproduction (Cole et al. 1990).

The list of alien amphibians and reptiles in Brazil comprises 136 species, including native Brazilian species that are found outside their natural distribution range (Fonseca et al. 2019). We suggest that $G$. underwoodi should now be included in this list.

\section{CONCLUSIONS}

Our results on morphological and molecular data of isolated populations of Gymnophthalmus from Amazonian savanna enclaves in the states of Amapá and Pará confirmed that to date only Gymnophthalmus vanzoi is known to occur in these enclaves. Gymnophthalmus underwoodi is recorded for the first time south of the Amazonas River, likely as the result of an accidental introduction in the region of Belém, where the species had not been recorded before 2012, despite being one of the best known regions in Amazonia regarding herpetofauna. The probable introduction route is through ships coming from countries where $G$. underwoodi is historically known to occur.

\section{ACKNOWLEDGMENTS}

We thank the two anonymous reviewers for their valuable suggestions of improvement to the manuscript. This work was developed at the Laboratory of Molecular Biology of Museu Paraense Emílio Goeldi (MPEG) with resources from the FINEp grant 'Parque analítico do MPEG: análise das transformaçóes da Amazonia e seus reflexos na sociobiodiversidade e na paisagem' (\# 0118003100). We thank Mr. Antonio Carlos for the detection and collection of the specimen from Mosqueiro. AOM is supported financially by Programa de Capacitação Institucional (MPEG/Ministério da Ciência, Tecnologia e Inovaçóes, grant \# 301022/2021-6). ALCP is thankful to Conselho Nacional de Desenvolvimento Científico e Tecnológico (CNPq) (grant \# 30.2611/20185 and PROTAX 44.462/2020). MVS was supported by a master's scholarship from Coordenação de Apoio à Formação de Pessoal de Nível Superior (CAPES) (process \# 88882.459754/2019-01). Part of this study was supported by CNPq (process \# 434362/2018-2).

\section{REFERENCES}

Alfonso, Y.U.; Casenave-Cambet, A.C.; Fong, A.; Díaz, L.M. 2012. First record of the unisexual lizard Gymnophthalmus underwoodi (Squamata: Gymnophthalmidae) in Cuba. Reptiles and Amphibians: Conservation and Natural History, 19: 57-59.

Alfonso, Y.U.; Hernandez, Z. 2017. New records for Gymnophthalmus underwoodi (Squamata: Gymnophthalmidae) suggest another entry pathway on eastern Cuba. Revista Cubana de Ciencias Biológicas, 5: 1-4. doi.org/10.17161/randa.v19i1.13844

Avila-Pires, T.C.S. 1995. Lizards of Brazilian Amazonia (Reptilia: Squamata). Zoologische Verhandelingen, 299: 1-706.

Avila-Pires, T.C.S.; Hoogmoed, M.S.; Rocha, W.A.D. 2010. Notes on the Vertebrates of northern Pará, Brazil: a forgotten part of the Guianan Region, I. Herpetofauna. Boletim do Museu Paraense Emílio Goeldi Ciências Naturais, 5: 13-112.

Avila-Pires, T.C.S.; Alves-Silva, K.R.; Barbosa L.; Correa F.S.; Cosenza J.F.; Costa-Rodrigues A.P.V.; et al. 2018. Changes in amphibian and reptile diversity over time in Parque Estadual do Utinga, Pará State, Brazil, a protected area surrounded by urbanization. Herpetology Notes, 11: 499-512.

Benavides, E.; Baum, R.; McClellan, D.; Sites Jr., J.W. 2007. Molecular phylogenetics of the lizard genus Microlophus (Squamata: Tropiduridae): aligning and retrieving indel signal from nuclear introns. Systematic Biology, 56: 776-797.

Breuil, M.; Serre-Collet, F. 2012. Gymnophthalmus underwoodi (Smooth-scaled Worm Lizard). Distribution. Caribbean Herpetology, 30: 1. doi: 10.31611/ch.30

Carvalho, C.M. 1999. Uma nova expécie de microteiideo do gênero Gymnophthalmus do estado de Roraima, Brasil (Sauria: Gymnophthalmidae). Papéis Avulsos de Zoologia, São Paulo, 40 [1997]: 161-174.

Cole, C.J.; Dessauer, H.C.; Townsend, C.R.; Arnold, M.G. 1990. Unisexual lizards of the genus Gymnophthalmus (Reptilia: Teiidae) in the neotropics: Genetics, origin, and systematics. American Museum Novitates, (2994): 1-29.

D'Angiolella, A.B.; Alvez, D.S.; Sodré, D.; Leite, L.; Phalan, B.T.; Nascimento, L.R.S.; Diele-Viegas, L.M. 2021. New occurrence records of Lepidodactylus lugubris (Duméril \& Bibron, 1836) (Squamata: Gekkonidae) for the Amazon and Atlantic Forest in Brazil. Cuadernos de Herpetología, 36: 1-6. doi:10.31017/ CdH.2021.(2020-058)

Duméril, A.M.C.; Bibron, G. 1839 Erpétologie générale ou histoire naturelle complete des reptiles. Tome 3. Librairie Encyclopédique de Roret, Paris, 517p. 
Fonseca, E.; Both, C.; Cechin, S.Z. 2019. Introduction pathways and socio-economic variables drive the distribution of alien amphibians and reptiles in a megadiverse country. Diversity and Distributions, 25: 1130-1141.

Galatti, U.; Estupiñan, R.A.; Dias, A.C.L.; Travassos, A.E.M. 2007. Anfíbios da área de pesquisa ecológica do Guamá-Apeg e região de Belém, Pará. In: Gomes, J.I.; Martins, M.B.; Martins-da-Silva, R.C.V.; Almeida, S.S. (Ed.). Mocambo: Diversidade e Dinâmica Biológica da Área de Pesquisa Ecológica do Guamá (APEG). Museu Paraense Emilio Goeldi / Embrapa Amazônia oriental, Belém, p.75-95.

Geurgas, S.R.; Rodrigues, M.T.; Moritz, C. 2008. The genus Coleodactylus (Sphaerodactylinae, Gekkota) revisited: a molecular phylogenetic perspective. Molecular Phylogenetics and Evolution, 49: 92-101.

Grant, C. 1958. A new Gymnophthalmus (Reptilia, Teiidae) from Barbados, B.W.I. Herpetologica, 14: 227-228.

Hall, T.A. 1999. BioEdit: a user-friendly biological sequence alignment editor and analysis program for Windows 95/98/NT. Nucleic Acids, 41: 95-98.

Hardy, L.M.; Cole, C.J.; Townsend, C.R. 1989. Parthenogenetic reproduction in the Neotropical unisexual lizard, Gymnophthalmus underwoodi (Reptilia: Teiidae). Journal of Morphology, 201:215-234.

Hoogmoed, M.S. 1973. Notes on the Herpetofauna of Surinam. IV. The Lizards and Amphisbaenians of Surinam. Springer Netherlands, Heidelberg, $419 \mathrm{p}$.

Hoogmoed, M.S.; Avila-Pires, T.C.S. 2015. Lepidodactylus lugubris (Duméril \& Bibron 1836) (Reptilia: Gekkonidae), an introduced lizard new for Brazil, with remarks on and correction of its distribution in the New World. Zootaxa, 4000: 90-110.

Katoh, K.; Kuma, K.; Toh, H.; Miyata, T. 2005. MAFFT version 5: improvement in accuracy of multiple sequence alignment. Nucleic Acids Research, 33: 511-518.

Katoh, K.; Rozewicki, J.; Yamada, K.D. 2019. MAFFT online service: multiple sequence alignment, interactive sequence choice and visualization. Briefings in Bioinformatics, 20: 1160-1166.

Katoh, K.; Toh, H. 2008. Recent developments in the MAFFT multiple sequence alignment program. Briefings in Bioinformatics, 9: 286-298.

Kizirian, D.A.; Cole, C.J. 1999. Origin of the Unisexual Lizard Gymnophthalmus underwoodi (Gymnophthalmidae) Inferred from Mitochondrial DNA Nucleotide Sequences. Molecular Phylogenetics and Evolution, 11: 394-400.

Kuraku, S.; Zmasek, C.M.; Nishimura, O.; Katoh, K. 2013. aLeaves facilitates on-demand exploration of metazoan gene family trees on MAFFT sequence alignment server with enhanced interactivity. Nucleic Acids Research, 41: 22-28.

Lanfear, R.; Frandsen, P.B.; Wright, A.M.; Senfeld, T.; Calcott, B. 2017. PartitionFinder 2: new methods for selecting partitioned models of evolution for molecular and morphological phylogenetic analyses. Molecular Biology and Evolution, 34: 772-773.

Merrem, B. 1820. Versuch eines Systems der Amphibien (Tentamen Systematis Amphibiorum). J. C. Kriegeri, Marburg, 191p.
Miller, M.A.; Pfeiffer, W.; Schwartz, T. 2010. Creating the CIPRES Science Gateway for inference of large phylogenetic trees. In: Proceedings of the 2010 Gateway Computing Environments Workshop, p.1-8. doi:10.1109/GCE.2010.5676129

Orchard, K. 2010. Gymnophthalmus underwoodi (Smooth-scaled Worm Lizard). Distribution. Caribbean Herpetology, 12: 1. doi: $10.31611 /$ ch. 12

Questel, K.; Boggio, J. 2012. Gymnophthalmus underwoodi (Smoothscaled Worm Lizard). Distribution. Caribbean Herpetology, 36: 1. doi: $10.31611 /$ ch.36

Prudente, A.L.C.; Sarmento, J.F.M.; Avila-Pires, T.C.S.; Maschio, G.; Sturaro, M.J. 2018. How much do we know about the diversity of Squamata (Reptilia) in the most degraded region of Amazonia? South American Journal of Herpetology, 13: 117-130.

Rand, S.; Humphrey, S.S. 1968. Interspecific competition in the tropical rain forest: ecological distribution among lizards at Belém, Pará. Proceedings of the United States National Museum 125 (3658): 1-17. doi:10.5479/si.00963801.125-3658.1

Recoder, R.S.; Dal Vechio, F.; Marques-Souza, S.; Teixeira Jr., M.; Silva-da-Silva, M.; Santos-Jr., A.P.; Ribeiro, S.; Barrio-Amorós, C.; Rodrigues, M.T. 2018. Geographic variation and taxonomy of red-tailed Gymnophthalmus (Squamata: Gymnophthalmidae) from Amazonian Savannas. Zootaxa, 4497: 61-81.

Ribeiro-Junior, M.A; Amaral, S. 2017. Catalogue of distribution of lizards (Reptilia: Squamata) from the Brazilian Amazonia. IV. Alopoglossidae, Gymnophthalmidae. Zootaxa, 4269: 151-196.

Snyder, S.J.; Schmidt, R.E.; McMullin, E.R.; Parker, B.F.; Ferus, H.L. 2017. Gymnophthalmus underwoodi Grant, 1958 (Reptilia: Gymnophthalmidae), a new record for the island of Montserrat. Check List, 13: 2153. doi: org/10.15560/13.3.2153

Stamatakis, A. 2014. RAxML Version 8: A tool for phylogenetic analysis and post-analysis of large phylogenies. Bioinformatics, 30: $1312-1313$.

Turk, P.A.; Wyszynski, N.N.; Powell, R.; Henderson, R.W. 2010. Population densities and water-loss rates of Gymnophthalmus pleii, Gymnophthalmus underwoodi (Gymnophthalmidae), and Sphaerodactylus fantasticus fuga (Sphaerodactylidae) on Dominica, West Indies. Salamandra, 46: 125-130.

Vaidya, G.; Lohman, D.J.; Meier, R. 2011. SequenceMatrix: concatenation software for the fast assembly of multi-gene datasets with character set and codon information. Cladistics, 27: $171-180$

Vanzolini, P.E.; Carvalho, C.M.D. 1991. Two sibling and sympatric species of Gymnophthalmus in Roraima, Brazil (Sauria: Teiidae). Papéis Avulsos de Zoologia, São Paulo, 37: 173-226.

Whiting, A.S.; Bauer, A.M.; Sites Jr., J.W. 2003. Phylogenetic relationships and limb loss in sub-Saharan African scincine lizards (Squamata: Scincidae). Molecular Phylogenetics and Evolution, 29: $582-598$.

\section{RECEIVED: $16 / 05 / 2021$ \\ ACCEPTED: 06/08/2021 \\ ASSOCIATE EDITOR: Claudia Keller}

